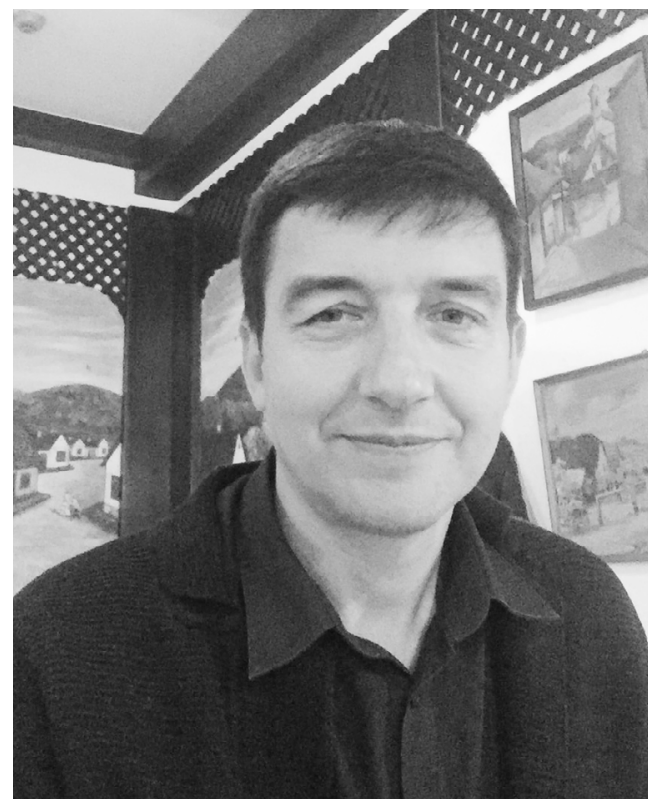

UDC 351.71:334.012

Lavrenty Dmitriy Stepanovich, post-graduate student, Taurida National Vernadsky University, Kyiv, Str. Ivana Kudri, 33, tel.; (050) 46227 22, e-mail:lavish@ukr.net ORCID: 0000-0003-3414-6705

Лаврентій Дмитро Степанович, аспірант, Таврійський національний університет імені В. I. Вернадського, м. Київ, вул. Івана Кудрі, 33, тел.: (050) 46227 22, e-mail:lavish@ukr.net

ORCID:0000-0003-3414-6705

Лаврентий Дмитрий Степанович, аспирант, Таврический начиональный университет имени В. И. Вернадского, 2. Киев, ул. Ивана Кудри, 33, тел.: (050) 46227 22,e-mail:lavish@ukr.net

ORCID: 0000-0003-3414-6705

DOI https://doi.org/10.31618/vadnd.v1i13.136

\title{
CATEGORIZATION OF PUBLIC-PRIVATE PARTNERSHIP IN THE CONCEPTUAL SPACE OF THE SOCIAL STATE
}

Abstract. The article studies the problematic issues of scientific understanding and the correlation of the notions of public-private/public-private partnership in a categorical series of concepts that reveal the essence and mechanisms of the functioning of a social state in the theory of public administration.

Is done semantic analysis a family of related scientific categories 'social partnership', 'public-private partnership', 'intersectoral partnership', 'state-private partnership' and 'municipal-private partnership', which mean the same process and are different only the definition of the range of subjects of social action in the application of public dialogue and the implementation of social policies aimed at building a social state in Ukraine.

It is argued that in the course of state-private partnership, the satisfaction of the society with the activities of state and local authorities, which, in turn, forms the trust of the people in power, stimulates them to fulfil their duties better. And this is a prerequisite for ensuring well-being in the country as a whole. Thus, the mechanism of public-private partnership is one of the key elements of a public (social) dialogue in the discursive space of state social policy that brings Ukraine closer to Europe, promotes the formation of a socially oriented economy and socially responsible governance as crucial elements for the development of a social state. Meanwhile, there is still no steady practices of partnership between 
public administration and civil society institutions in areas such as the formation of public policy, its monitoring, public control over the activities of central executive authorities, local governments, and budget financing agencies, etc. at present.

The article reveals the importance of public-private partnership as a key mechanism of the state's social policy aimed at achieving the Sustainable Development Goals for Ukraine.

Keywords: public-private partnership, public-private partnership, Sustainable Development Goals, social partnership, social policy.

\section{КАТЕГОРИЗАЦІЯ ПУБЛІЧНО-ПРИВАТНОГО ПАРТНЕРСТВА В ПОНЯТІЙНОМУ ПРОСТОРІ СОЦІАЛЬНОЇ ДЕРЖАВИ}

Анотація. Досліджуються проблемні питання наукового розуміння та співвідношення поняття публічно-приватного/державно-приватного партнерства у категоріальному ряду понять, що розкривають сутність та механізми функціонування соціальної держави в теорії публічного врядування.

Зроблено семантичний аналіз сімейства споріднених таких наукових категорій: “соціальне партнерство”, “публічно-приватне партнерство”, “міжсекторальне партнерство”, “державно-приватне партнерство” та “муніципально-приватне партнерство”, котрі означають один і той самий процес та відрізняються лише визначенням кола суб'єктів соціальних дій в ході застосування публічного діалогу та реалізації соціальної політики, спрямованої на розбудову соціальної держави в Україні.

Стверджується, що в ході державно-приватного партнерства виникає задоволеність суспільства діяльністю державних та місцевих органів влади, котра, у свою чергу, формує у громадян довіру до влади, стимулює їх до кращого виконання своїх обов'язків, а це є передумовою забезпечення добробуту в країні загалом. Отже, механізм публічно-приватного партнерства є одним з ключових елементів публічного (соціального) діалогу в дискурсному просторі державної соціальної політики, що наближує Україну до Свропи, сприяє формуванню соціально орієнтованої економіки та соціально відповідального врядування як визначальних елементів розбудови соціальної держави. Проте наразі відсутні сталі практики партнерства інститутів державного управління та громадянського суспільства в таких сферах, як формування державної політики, її моніторинг, громадський контроль за діяльністю центральних органів виконавчої влади, органів місцевого самоврядування, установ з бюджетним фінансуванням тощо.

Розкривається значення публічно-приватного партнерства як ключового механізму соціальної політики держави, спрямованої на досягнення цілей сталого розвитку для України.

Ключові слова: публічно-приватне партнерство, державно-приватне партнерство, цілі сталого розвитку, соціальне партнерство, соціальна політика. 


\section{КАТЕГОРИЗАЦИЯ ПУБЛИЧНО-ЧАСТНОГО ПАРТНЕРСТВА В ПОНЯТИЙНОМ ПРОСТРАНСТВЕ СОЦИАЛЬНОГО ГОСУДАРСТВА}

Аннотация. Исследуются проблемные вопросы научного понимания и соотношения понятий публично-частного/государственно-частного партнерства в категориальном ряду понятий, раскрывающих сущность и механизмы функционирования социального государства в теории публичного управления.

Сделан семантический анализ семейства родственных таких научных категорий: “социальное партнерство”, “публично-частное партнерство”, "межсекторальное партнерство", “государственно-частное партнерство” и "муниципально-частное партнерство”, означающие один и тот же процесс и отличающиеся только определением круга субъектов социальной деятельности в ходе применения общественного диалога и осуществления социальной политики, направленной на развитие государства всеобщего благосостояния в Украине. Утверждается, что в ходе государственно-частного партнерства возникает удовлетворенность общества деятельностью государственных и местных органов власти, которая, в свою очередь, формирует доверие граждан к органам власти, стимулирует их лучше выполнять свои обязанности, а это является предпосылкой обеспечения благосостояния страны в целом. Таким образом механизм государственно-частного партнерства является одним из ключевых элементов публичного (социального) диалога в дискурсном пространстве государственной социальной политики, приближающей Украину в Европу, способствующей формированию социально-ориентированной экономики и социально ответственного управления как определяющих элементов социального государства. Однако сейчас еще отсутствуют стойкие практики партнерства институтов государственного управления и гражданского общества в таких сферах, как формирование государственной политики и ее мониторинг, общественный контроль над деятельностью центральных органов исполнительной власти, органов местного самоуправления, учреждений с бюджетным финансированием и т. д.

Раскрывается значение государственно-частного партнерства как ключевого механизма социальной политики государства, направленной на достижение целей устойчивого развития для Украины.

Ключевые слова: публично-частное партнерство, государственно-частное партнерство, цели устойчивого развития, социальное партнерство, социальная политика.

Introduction. The third millennium has exacerbated the problem of the further development of mankind, which, according to many criteria of quality of life, has reached a critical point. The world community has twice returned to this issue at the highest level of the UN Summit: 189 countries of the world 
adopted the Millennium Declaration in 2000, and the United Nations Summit on Sustainable Development and the adoption of the new Human Development Agenda adopted the Final Document 'Transforming Our World: An Agenda for Sustainable Development to 2030' in the framework of the 70th session of the UN General Assembly in New York in 2015. This document contains 17 Global Sustainable Development Goals, deployed and detailed in 169 tasks.

Ukraine, like most other countries of the world, has acceded to these commitments and has done the appropriate work to adapt them to the specifics of national development. On September 15, 2017, the Government of Ukraine presented the National Report 'The Objectives of Sustainable Development: Ukraine', which defines the basic indicators for achieving the Goals of Sustainable Development, hereinafter referred to as the GSD. The report presents the national system of the GSD containing 17 goals detailed in 86 development tasks and 172 indicators for monitoring their implementation in four areas as follows:

1. Fair social development;

2. Sustainable growth and employment;

3. Effective management;

4. Environmental equilibrium and sustainable development.

One of Ukraine's tasks is to develop partnerships between government and business to achieve the Goals of Sustainable Development, measured by the number of public-private partnership projects [11, p. 124-125].

All this leads to a revival of scientific interest in the consideration of the phe- nomenon of public-private partnership, especially in its relationship with the categories of social state and social development, which are enshrined as one of the key areas of the GSD.

Analysis of recent scientific research. The problems of state-private sector partnership development in modern scientific discourse (both foreign and domestic) are being studied quite actively. In particular, among the most recent publications tangible to the goal, attention is paid to the work of such researchers as V. Butenko [1], O. Vasylieva [2], N. Hvozdyk [3], M. Deich [4], K. Dubych [5], M. Koliada [7], S. Maistro [9], O. Makara [10], V. Mamonova [11], O. Siduniak [14], and others. This year was published an interesting and fairly lengthy, both in the amount and scope of scientific and analytical research specialist of both the World Bank specialist Jeffrey Delmon [18] and Joshua Newman of the Australian University of Flinders [21].

Problem statement. The mentioned authors reveal certain aspects of publicprivate partnership, however, they did not focus on the complex study of scientific understanding and the relation between the concept of public-private and state-private partnership in a number of concepts that reveal the essence and mechanisms of the functioning of a social state in the theory of public administration. That is precisely the purpose of this scientific intelligence.

Description of the main results of the study. Historically, the same phenomenon of joint actions on the basis of partnership relations between state authorities, local self-government, business structures and civil society or- 
ganizations in Western European and national science is called something different, as it would sound in the literal translation. The term 'Public-Private Partnerships' (PPP) is widely used, which literally means 'public-private partnerships' (PPP), while Ukraine, along with most CIS countries, operates on the concept of 'State-Private Partnership' (SPP) for the EU and North America and Australia.

In our opinion, this kind of interpretation in the post-Soviet space was reflected in the perception of the state as the dominant subject of relations with other traditional sectors (business and civil society) in the post-Soviet space. In the context of the European integration course, Ukraine should also have the appropriate 'decommunization' of similar scientific terms bearing the expressive burden of the state as a social dominant. The processes of decentralization, started in our country, are gradually bringing Ukraine closer to Europe, where public authorities, in particular, the bodies of public governance, in the sense of the equal role of these bodies of state executive power, as well as municipal bodies, institutions, are no longer playing a role in social and political life civil society, involved in the development and implementation of public policy.

At the same time, the categorical West-based phrase 'Public Private Partnership' is wider in its interpretation than its Ukrainian counterpart, since the definition of 'public', among the entities of the relevant partnership, refers not only to state authorities but also establishments and institutions of local self-government and institutions of civil society that is, all social forces which aim to achieve certain public interests. In turn, the definition of 'private' to the range of subjects of the partnership does not refer to a specific individual, but representatives of business, economic sector, at the disposal of which there are financial and other resources and the main purpose of which is to generate profit or increase social capital campaign, its image through participation in socially significant projects.

A short definition of the World Bank is typical in this regard: "public-private partnership is an agreement between public and private partners seeking to produce and provide infrastructure services whose purpose is to increase the efficiency of budget financing and investment attraction' [17]. The European Commission adds to this definition the 'division of powers and responsibilities, joint investment of resources, distribution of responsibility or risk and, ideally, benefits' [19].

On this basis, we consider the wider use of the notion of 'public-private partnership', which is wider than the 'state-private partnership' commonly accepted by us, due to the expansion of the subjects of such a partnership (because the second concept leaves only the state as the designated subject not taking into account the possibility of participation in similar projects of other bodies of public authority, in particular local self-government bodies by definition). In this case, in the case where the partnership agreement is bilateral and is concluded between the private investor and the state body, we can speak about the identity for such a case of both above mentioned terms. 
Finally, a simple syntactic analysis of the exploratory definition as a compound phrase clearly indicates the process, the action (partnership) and the subjects of this process (state and private structure). But even in the encyclopaedia of public administration, the SPP is disclosed as 'a form of cooperation between public authorities and a private institution' (i.e. 'In a clear sense, not as SPP, but as the PP', the author said) further: 'regarding the provision of services in areas that are commonly considered recipients of budget financing' [11, p. 79] ('Today, more and more recipient recipients of budget financing go to the municipal government, not the state but the public authorities in Ukraine', the author said).

In the same vein, with the isolation of all subjects of public governance, and not just state bodies, M. Solodarenko gives his definition of state-private partnership, under which such ' $a$ partnership' should be understood as legal, voluntary and mutually beneficial cooperation between the state, local self-government bodies and private business, during which the union of resources and interests of the parties takes place, the distribution of rights in certain proportions, responsibilities, results and risks for the effective implementation of investment projects and solving the problems of socio-economic development in accordance with the interests of civil society [15, p. 165]. An attempt to squeeze out all possible partners of the partnership can be characterized by the attempt of $\mathrm{N}$. Ilchenko to introduce into the scientific circle the concept of 'state-private-public partnership' [6, p. 34]. In the literature, you can also find rarely used constructions 'intersectoral partnership', and 'municipal-private partnership', etc.

In our opinion, the most successful is the definition of D. Grimzee and M. Lewis, which define public-private partnership as 'an agreement by which the public administration sector enters long-term contractual relations with the private sector in order to implement a private partner in the construction of public sector infrastructure facilities and managing them or for providing services (using appropriate infrastructure) to the population on behalf of the organization of the public sector' [102, p. 248].

Then we anatomize in the same semantic plan 'partnership'. This concept necessarily implies a joint activity and a common goal of this activity. That is, the 'partnership' as a scientific category indicates not only the partnership nature of the relations between state institutions, municipal institutions, economic institutions and public institutions, but necessarily involves the achievement of a specific goal or specific goals and objectives of public-private partnership. And at this stage, we obtain the integral unity of the micro and macro levels of society's social life, since, according to Jeffrey Delmon's definition, public-private partnership as a form of infrastructure investment at the socio-economic micro-level is crucial for achieving the main social goals of the modern state as economic growth, quality of life, reduction of poverty, access to education, and health care, etc. [18].

Here again, we are returning to the Goals of Sustainable Development (GSD), which, in the broadest generalization, set the task of developing a social state, and, in a concrete application, 
called for 'to stimulate and encourage an effective partnership between public organizations, between the public and private sectors and between civil society organizations, based on experience and strategy of using partner resources' [12, p. 172].

This gives us the opportunity to try to outline and characterize the subject field of concepts that reveal the essence and mechanisms of the functioning of a social state in the theory of public administration (see Fig.). The logical chain of research leads from the universal Millennium Development Goals-
Sustainable Development Goals to the specified Sustainable Development Goals for Ukraine, in particular, with the development of a social state with a socially responsible administration in our society that should guarantee citizens the necessary social security.

M. Deich notes that socially responsible management provides for a certain level of voluntary response to social problems on the part of an entity that goes beyond the limits defined by law or regulatory authorities [4, p. 29]. At the same time, in the opinion of Professor S. Maistro, "the mechanism of SPP

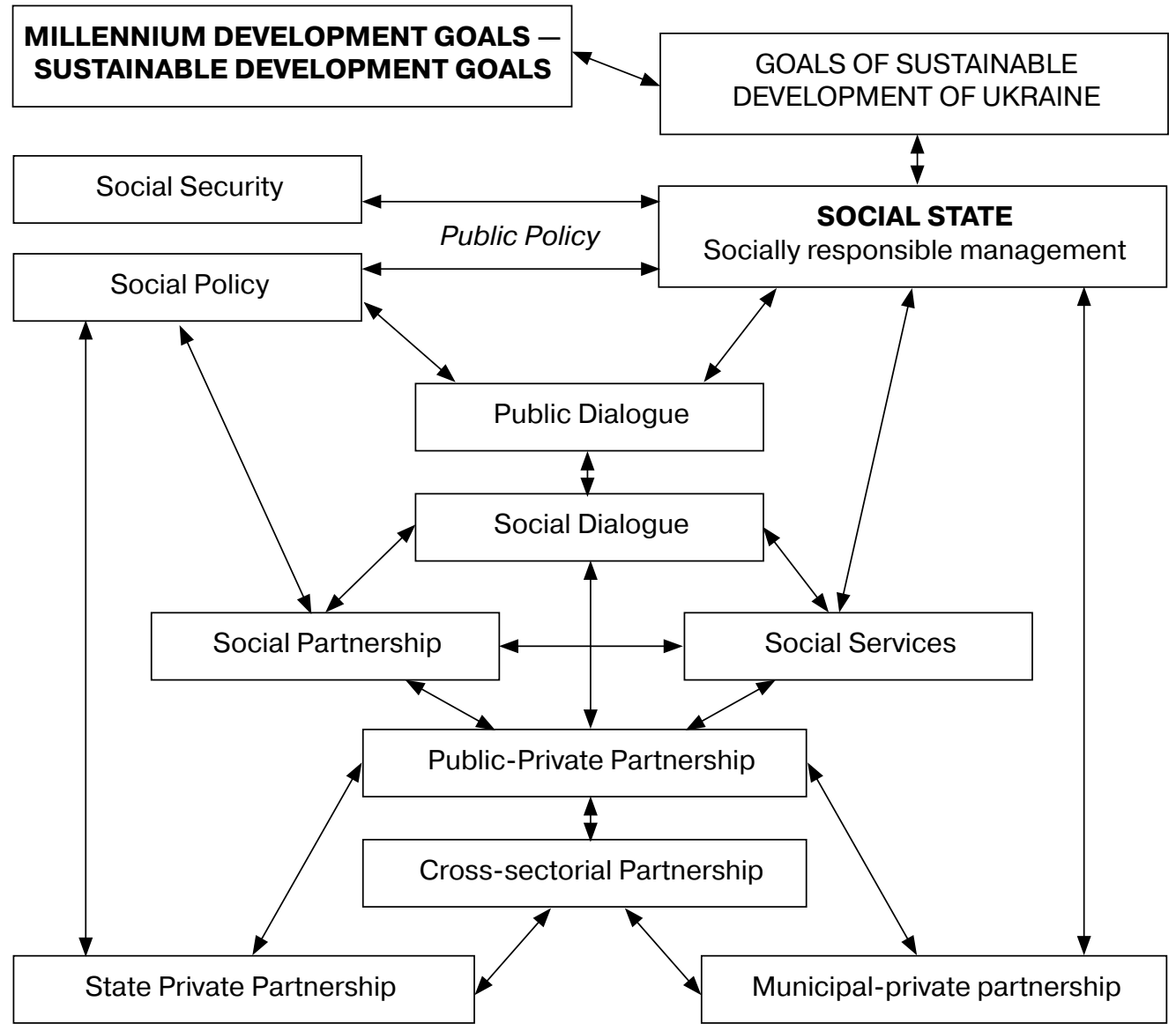

The place of public-private partnership in the subject field of the social state 
forms the basis for the joint responsibility of the state, community and business for the development of sectors of priority importance' [9, p. 246].

The tasks of building a social state are realized in the course of implementing a public policy, first of all, as a significant component of it as a social policy with its contemporary focus on widespread reform of the social sphere of Ukraine [2]. As a matter of fact, the social policy as a whole, as well as the PPP, according to Professor O. Siduni$\mathrm{ak}$, are intended to ensure the creation of a social infrastructure that provides a normal daily life-sustaining activity of the society [14, p. 51].

The main format of social-power interaction in a social state is recognized as a public dialogue or a social dialogue (these concepts do not have a fundamental difference, unless the first involves again greater range of subjects interaction). At the same time, specialists in public administration are more inclined to use the notion of 'public dialogue' (Professors O. Krutyi, O. Radchenko [8]), instead sociologists and lawyers widely use the concept of 'social dialogue' (M. Koliada [7]).

One of the key functions of a social state is to provide citizens with social services guaranteed by the Constitution. K. Dubych focuses on this: 'statepublic, intersectoral cooperation on the provision of social services is an integral component, an important state-management mechanism that in practice enables the implementation of the principles of the provision of social services' [5, p. 120]. In the same way, O. Makarov noted the reduction of the budget deficit at all levels of public administration and the improvement of the quality of public services through the involvement of private investors in the publicprivate partnership [10, p. 367].

M. Koliada shifts the logical chain from social dialogue to social partnership, emphasizing that on the one hand, social dialogue involves social partnership, but on the other hand it acts as an element of social partnership, correlating among themselves as a process and a goal [7, p. 292]. At the same time, N. Hvozdyk defines social partnership as one of the basic principles of functioning of a modern democratic society, an important instrument for the implementation of the social policy of the state, as a means of preventing and resolving social conflicts [3, p. 17]. According to the researcher, the main sphere of realization of social partnership is the sphere of social-labour relations, and its key element is social dialogue [ibid].

V. Butenko emphasizes the special role of social partnership during the development of a social state. 'Historical experience of the development of many countries has shown that eventually all countries come to understand the need to resolve social conflicts, confrontation, proceeding from economic and environmental crises through the development of such an institution as a social partnership that, under certain specific conditions, meets the needs of society and ensures social stability' [1, p. 61].

In turn, social partnership in the semantic-morphological decomposition methodology completely absorbs itself as a public-private, inter-sectorial partnership, and its structural components as public-private and municipal-private partnership (the main purpose of which Professor O. Serdiukova sees attraction of investments in development of the lo- 
cal economy and ensuring the improvement of the state of the objects of state and communal property [13, p. 328]).

Thus, we can talk about a family of related scientific categories 'social partnership', 'public-private partnership', 'intersectoral partnership', 'stateprivate partnership' and 'municipalprivate partnership', which mean the same process and are different only the definition of the range of subjects of social action in the application of public/ social dialogue and the implementation of social policies aimed at building a social state in Ukraine.

Ukrainian officials honestly admit that, despite the fact that it has been developed a legal framework for stateprivate partnership for Ukraine, but the real pace of its practical application is unsatisfactory. Existing projects mainly relate to the implementation of current government procurement and do not include tangible investment components. One of the main reasons for this state of affairs is the lack of trust in the state as a business partner due to the continuing instability of public finances, the volatility of legislation with high levels of corruption, including at the level of the middle management who is responsible for implementation of state-private partnership projects. There are no steady practices of partnership between public administration and civil society institutions in areas such as the formation of public policy, its monitoring, public control over the activities of central executive authorities, local governments, and budget financing agencies, etc. at present [12, p. 125-126]. This requires more active use of the PPP tools during state-building reforms taking place in Ukraine now. The existing steps and even the plan of the Ukrainian government are extremely scarce, because only 5 units were in 2017,15 will be in 2022 and 30 will be in 2027 according to the mentioned National Report 'The Objectives of Sustainable Development: Ukraine'. And despite the fact that 6 such projects, for example, were implemented in 2011 and 16 projects were implemented in 2012 in Ukraine! It turns out that our government deliberately 'reduces the bar', rather than focusing on leaders (the UK annually concludes up to 80 new partnership agreements, with more than 30 such agreements in the healthcare sector alone).

Conclusions. In summing up the research, we state the statement that in the course of state-private partnership, the satisfaction of the society with the activities of state and local authorities, which, in turn, forms the trust of the people in power, stimulates them to fulfil their duties better. And this is a prerequisite for ensuring well-being in the country as a whole [14, p. 52]. Thus, the mechanism of public-private partnership is one of the key elements of a public (social) dialogue in the discursive space of state social policy that brings Ukraine closer to Europe, promotes the formation of a socially oriented economy and socially responsible governance as crucial elements for the development of a social state.

Prospect for further research is the need to study the development of the institutional environment of state-private partnership; improvement of the mechanism of public administration in the field of ensuring the development of such a partnership; improving the effectiveness of the public support mechanism in state-private partnership. 


\section{REFERENCES}

1. Ministerstvo ekonomichnoho rozvytku i torhivli Ukrainy (2017), Natsional'na dopovid' "Tsili Staloho Rozvytku: Ukraina”, Kyiv, Ukraine.

2. Worldbank (2016), "About Public-Private Partnerships" // The Public-Private Partnership in Infrastructure Resource Center of Worldbank, available at: https://ppp.worldbank.org/publicprivate-partnership/about-public-private-partnerships

3. European Commission (2003), Guidelines for Successful Public-Private Partnerships, available at: http:// ec.europa.eu/regional_policy/sources/docgener /guides/ppp_en.pdf

4. Mamonova V. V. (2011), "Derzhavnopryvatne partnerstvo" Entsyklopediia derzhavnoho upravlinnia, T. 5 : Terytorial'ne upravlinnia, p. 79-81.

5. Solodarenko M. (2015), "Sutnisno-teoretychni pidkhody do rozuminnia katehorii derzhavno-pryvatne partnerstvo", Naukovyj visnyk, vol. 3, p. 156-172.

6. Il'chenko N. (2014), "Synerhiia mizhsektornoho partnerstva $\mathrm{v}$ sotsial'noekonomichnomu rozvytku hromady", Zbirnyk naukovykh prats' Cherkas'koho derzhavnoho tekhnolohichnoho universytetu. vol. 37(2), p. 33-42.

7. Grimsey D., and Lewis M. K. (2002) "Evaluating the risks of public private partnerships for infrastructure projects", International Journal of Project Management 20(2). p. 240-252.

8. Delmon J. (2017) Public-Private Partnership Projects in Infrastructure: An Essential Guide for Policy Makers, Cambridge University Press, Cambridge, UK.

9. Dejch M. (2011), "Sotsial'ne partnerstvo iak instrument vzaiemouzghodzhennia sotsial'nykh obov'iazkiv ta sotsial'noi vidpovidal'nosti" Ukraina: aspekty pratsi, vol. 6, p. 27-34.
10. Majstro $S$. V. (2016), "Derzhavno-pryvatne partnerstvo iak instrument zabezpechennia staloho sotsial'no-ekonomichnoho rozvytku rehionu", Visnyk Natsional'noho universytetu tsyvil'noho zakhystu Ukrainy. Seriia: Derzhavne upravlinnia, vol. 2, p. 243-249.

11. Vasyl'ieva O. I. (2014), "Napriamy zastosuvannia derzhavno-pryvatnoho partnerstva v sotsial'nij sferi”, Derzhavne upravlinnia: udoskonalennia ta rozvytok, vol. 10, http://nbuv.gov.ua/ UJRN/Duur_2014_10_3

12. Siduniak O.V.(2014), "Derzhavno-pryvatne partnerstvo: sutnist', dosvid ta mozhlyvosti vykorystannia u sotsial'nij sferi”, Visnyk Chernivets'koho torhovel'no-ekonomichnohoinstytutu,vol.1, p. 46-52.

13. Krutij O. M., Radchenko O. V. (2015) Publichnyj dialoh $\mathrm{v}$ systemi politychnoi kul'tury demokratychnoho suspil'stva, Vyd-vo ADNDU, Kharkiv, Ukraine.

14. Koliada M. O. (2013), "Spivvidnoshennia poniat' "sotsial'ne partnerstvo" i "sotsial'nyj dialoh" u trudovomu pravi: teoriia ta praktyka”, Publichne pravo, vol. 4, p. 291-296.

15. Dubych K. V. (2013), "Partnerstvo derzhavnoho ta nederzhavnoho suspil'nykh sektoriv iak efektyvnyj mekhanizm upravlinnia u sferi nadannia sotsial'nykh posluh u krainakh Yevrosoiuzu", Derzhavne upravlinnia: teoriia ta praktyka, vol. 2, p. 117-128.

16. Makara O. V. (2014), "Derzhavno-pryvatne partnerstvo v konteksti sotsial'no oriientovanoho rozvytku krainy", Naukovyj visnyk NLTU Ukrainy, vol. 24.1, p. 366-371.

17. Hvozdyk N. M. (2014), "Znachennia sotsial'noho partnerstva u stymuliuvanni investytsij u liuds'kyj kapital systemy Ukoopspilky" Finansovyj prostir, vol. 2, p. 16-20.

18. Butenko V. M. (2014), "Instytutsijni zasady rozvytku sotsial'noho partner- 
stva v Ukraini” Zbirnyk naukovykh prats' Tavrijs'koho derzhavnoho ahrotekhnolohichnoho universytetu, vol. 1, p. 61-65.

19. Serdiukova O. Ye. (2012), "Derzhavno-pryvatne partnerstvo iak instrument innovatsijnoho rozvytku terytorial'nykh hromad", Efektyvnist' derzhavnoho upravlinnia, vol. 32, p. 323329.

20. Newman J. (2017) Governing PublicPrivate Partnerships, McGill-Queen's University Press, UK.

21. Natsional'nyj instytut stratehichnykh doslidzhen' (2017), Schodo rozvytku derzhavno-pryvatnoho partnerstva iak mekhanizmu aktyvizatsii investytsijnoi diial'nosti v Ukraini: Analitychna zapyska, available at: http://www.niss. gov.ua/articles/816

\section{СПИСОК ВИКОРИСТАНИХ ДЖЕРЕЛ}

1. Національна доповідь “Цілі Сталого Розвитку: Україна” [Текст] / Miністерство економічного розвитку i торгівлі України, 2017. - Київ : Б. м., 2017. - $176 \mathrm{c}$.

2. About Public-Private Partnerships [Електронний ресурс] // The PublicPrivate Partnership in Infrastructure Resource Center of Worldbank. Режим доступу: https://ppp.worldbank.org/public-private-partnership/ about-public-private-partnerships

3. Guidelines for Successful Public-Private Partnerships / European Commission, 2003 [Електронний ресурс]. Режим доступу: http://ec.europa.eu/ regional policy/sources/docgener/ guides/ppp_en.pdf

4. Мамонова В. В. Державно-приватне партнерство / В. В. Мамонова // Енциклопедія державного управління: у 8 т. / Нац. акад. держ. упр. при Президентові України; наук.-ред. колегія : Ю. В. Ковбасюк (голова) та ін. - Т. 5 : Територіальне управління. - 2011. - С. 79-81.

5. Солодаренко M. Сутнісно-теоретичні підходи до розуміння категорії державно-приватне партнерство / М. Солодаренко // Наук. вісн. [Одеського нац. екон. ун-ту]. 2015. - № 3. - C. 156-172.

6. Ільченко $H$. Синергія міжсекторного партнерства в соціально-економічному розвитку громади [Текст] / Н. Ільченко // Зб. наук. пр. Черкаського держ. технологічного ун-ту. Серія : Економічні науки. - 2014. Вип. 37 (2). - С. 33-42.

7. Grimsey D., and Lewis M. K. (2002) Evaluating the risks of public private partnerships for infrastructure pro-jects // International Journal of Project Management 20 (2). P. 240-252.

8. Delmon J. Public-Private Partnership Projects in Infrastructure: An Essential Guide for Policy Makers / J. Delmon.Cambridge : Cambridge University Press, 2017. - 256 p.

9. Дейч М. Соціальне партнерство як інструмент взаємоузгодження соціальних обов'язків та соціальної відповідальності [Текст] / М. Дейч // Україна: аспекти праці. - 2011. № 6. - С. 27-34.

10. Майстро C. В. Державно-приватне партнерство як інструмент забезпечення сталого соціально-економічного розвитку регіону [Текст] / С. В. Майстро // Вісн. Нац. ун-ту цивільного захисту України. Серія : Державне управління. - 2016. Вип. 2. - С. 243-249.

11. Васильєва O. I. Напрями застосування державно-приватного партнерства в соціальній сфері [Електронний ресурс] / О. І. Васильєва // Державне управління: удосконалення та розвиток. - 2014. - № 10. Режим доступу: http://nbuv.gov.ua/ UJRN/Duur_2014_10_3 
12. Сідуняк О. В. Державно-приватне партнерство: сутність, досвід та можливості використання у соціальній сфері / О. В. Сідуняк // Вісн. Чернівецького торговельно-економічного ін-ту. - 2014. - № 1. - С. 46-52.

13. Крутій О. М. Публічний діалог в системі політичної культури демократичного суспільства : монографія / О. М. Крутій, О. В. Радченко. Х. : Вид-во АДНДУ, 2015. - 320 с.

14. КолядаМ.О.Співвідношенняпонять “соціальне партнерство” і “соціальний діалог” у трудовому праві: теорія та практика / М. О. Коляда // Публічне право. - 2013. - № 4. C. 291-296.

15. Дубич К. В. Партнерство державного та недержавного суспільних секторів як ефективний механізм управління у сфері надання соціальних послуг у країнах Свросоюзу [Текст] / К. В. Дубич // Державне управління: теорія та практика. - 2013. № 2. - C. 117-128.

16. Макара О. В. Державно-приватне партнерство в контексті соціально орієнтованого розвитку країни [Електронний ресурс] / О. В. Макара // Наук. вісн. НЛТУ України. 2014. - Вип. 24.1. - С. 366-371.
17. Гвоздик Н. М. Значення соціального партнерства у стимулюванні інвестицій у людський капітал системи Укоопспілки / Н. М. Гвоздик // Фінансовий простір. - 2014. - № 2. C. $16-20$.

18. Бутенко B. М. Інституційні засади розвитку соціального партнерства в Україні [Текст] / В. М. Бутенко // 3б. наук. пр. Таврійського держ. агротехнол. ун-ту. -2014 . - № 1. C. 61-65.

19. СердюковаО.С.Державно-приватне партнерство як інструмент інноваційного розвитку територіальних громад / О. С. Сердюкова // Ефективність державного управління. - 2012. - Вип. 32. - С. 323 329.

20. Newman J. Governing Public-Private Partnerships / J. Newman. - McGillQueen's University Press, 2017. $200 \mathrm{p}$.

21. Щодо розвитку державно-приватного партнерства як механізму активізації інвестиційної діяльності в Україні: Аналітична записка [Електронний ресурс] // Нац. ін-т стратегічних досліджень. - Режим доступу: http://www.niss.gov.ua/ articles/816 